\title{
Parental Control and Relational Aggression in Adolescence: Mediator Role of Emotion Regulation
}

\section{Ergenlikte Ebeveyn Kontrolü ve İlişkisel Saldırganlık: Duygu Düzenlemenin Aracı Rolü}

\author{
Seda Erzi ${ }^{1}$, Havva Ekși ${ }^{2}$
}

\begin{abstract}
:
The aim of this study is to examine the relational aggression of adolescents in terms of parental behavioral and parental psychological control with emotion regulation. In the tested model, the mediator role of emotion regulation between the psychological control of parents and adolescents' relational aggression was examined in male and female samples separately. Accordingly, 156 females and 164 males who are high school students, aged between 14 and 17, living in Zonguldak province of Turkey participated in the study. Participants answered Socio-Demographic information form, Relational Aggression in Friendship Relations Scale, Emotion Regulation Difficulty Scale, Psychological Control Scale, and Behavioral Control Scale, respectively. The findings of the study showed that emotion regulation had a mediator role in the relationship between parents' psychological control and relational aggression of male and female adolescents. In addition, father's and mother's behavioral control are negatively correlated with relational aggression, and emotion regulation has a mediator role in the relationship between only father's behavioral control and relational aggression of male and female adolescents. While psychological control increases the relational aggression of adolescents and the difficulty in emotion regulation, behavioral control decreases the relational aggression and emotion regulation difficulties. The findings of the study were discussed in the light of the relevant literature.
\end{abstract}

Keywords: Adolescence, Emotion Regulation, Relational Aggression, Psychological Control, Behavioral Control

${ }^{1}$ Assistan Professor, Maltepe University, Psychology Department, İstanbul-Turkey,Orcid İd: https://orcid.org/ 00000003-4450-158X

${ }^{2}$ Expert, Zonguldak Provincial Directorate of Family, Labor and Social Services, Zonguldak-Turkey, Orcid İd: https://orcid.org/ 0000-0003-1628-1241

Address of Correspondence/Yazşma Adresi: Maltepe University, Psychology Department, İstanbul-Turkey, E-mail: sedaerzi@maltepe.edu.tr

Date of Received/Geliş Tarihi: 01.03.2021, Date of Revision/Düzeltme Tarihi: 28.03.2021, Date of Acceptance/Kabul Tarihi: 04.04.2021, Date of Online Publication/Çevirimiçi Yayın Tarihi: 27.05.2021

Citing/Referans Gösterimi: Erzi, S., Ekşi, H. (2021). Parental Control and Relational Aggression in Adolescence: Mediator Role of Emotion Regulation, Cyprus Turkish Journal of Psychiatry \& Psychology, 3(2): 106-114.

(C) 2021 The Author(s). Published by Cyprus Mental Health Institute / Cyprus Turkish Journal of Psychiatry and Psychology (www.ktppder gisi.com). This article is an open access article distributed under the terms and conditions of the Creative Commons Attribution 4.0 license which permits use, sharing, adaptation, distribution and reproduction in any medium or format, provided the original work is properly cited and is not used for commercial purposes. https://creativecommons.org/licenses/by-nc-sa/4.0/ 


\section{Öz:}

Bu çalışmanın amacı, ergenlerin ilişkisel saldırganlığının, ebeveynin davranışsal ve psikolojik kontrolü ile duygu düzenleme bakımından incelenmesidir. Test edilen modelde, annenin ve babanın psikolojik kontrolü ile kız ve erkek ergenlerin ilişkisel saldırganlığı arasındaki ilişkide duygu düzenlemenin aracı rolü incelenmiştir. $\mathrm{Bu}$ doğrultuda, Zonguldak ilinde yaşayan, yaşları 14 ile 17 arasında olan, 156 kız ve 164 erkek lise öğrencisi çalışmaya katılmıştır. Katılımcılar sırasıyla, sosyodemografik bilgi formu, Arkadaşlık İlişkilerinde İlişkisel Saldırganlık Ölçeği, Duygu Düzenleme Güçlüğü Ölçeği, Psikolojik Kontrol Ölçeği ve Davranışsal Kontrol Ölçeğini yanıtlamışlardır. Çalışmanın bulguları, duygu düzenlemenin, hem annenin hem de babanın psikolojik kontrolü ve ilişkisel saldırganlık arasındaki ilişkide aracı rolü olduğunu göstermiş̧tir. Bunun yanı sıra, babanın ve annenin davranışsal kontrolü ilişkisel saldırganlıkla negatif yönde ilişkilidir ve yalnızca babanın davranışsal kontrolü ve iliş̧isel saldırganlık arasındaki ilişkide duygu düzenlemenin aracı rolü vardır. Psikolojik kontrolün, ergenlerin ilişkisel saldırganlığını arttırırken, duygu düzenleme güçlüğünü de arttırdığı, bunun yanında davranışsal kontrolün, ilişkisel saldırganlığı ve duygu düzenleme güçlüğünü azalttığı görülmüştür. Çalışmanın bulguları ilgili literatür eşliğinde tartışılmıştır.

Anahtar Kelimeler: Ergenlik, Duygu Düzenleme, İlişkisel Saldırganlık, Psikolojik Kontrol, Davranışsal Kontrol

\section{Giriş}

Ergenlik dönemi, fiziksel, ruhsal ve sosyal alanda birtakım değişimlerin meydana geldiği, bu bağlamda bireyin ve sosyal çevresinin birtakım uyum problemleri ile karşılaşabildiği bir dönemdir. Stanley Hall tarafından "firtına ve stres" dönemi olarak isimlendirilen bu dönemde birey, duygu durum değişimleri ve çatışmalar yaşar (Santrock, 2014). Ergenlik, aynı zamanda, sosyal ilişkilerin duygusal yoğunluk bakımdan değişim gösterdiği, yakın ilişkilerin kurulmaya başlandığı dolayısıyla ilişkisel saldırganlığın görülme sıklığının artış gösterdiği bir dönemdir (Zimmer-Gembeck ve ark. 2014). Buradan hareketle, bu araştırmanın amacı ergenlikte görülen ilişkisel saldırganlığı, ebeveyn kontrolü ve ergenin duygu düzenleme becerileri bakımından incelemektir.

Saldırganlık, başka bir organizmaya yönelik, şiddet içeren ve zarar vermeyi hedefleyen eylemler bütünü olarak tanımlanmakta, fiziksel, sözel ve ilişkisel olmak üzere alt kategorilere ayrılmaktadır (Dodge, Coie ve Lynam, 2006; Shaffer, 2008). Araştırmacılar, son yıllarda yapılan çalışmaların, saldırganlığın fiziksel olmayan biçimlerine daha fazla ağırlık verdiğini göstermektedir. Örneğin, Voulgaridou ve Kokkinos (2015) yaptıkları derlemede, yalnızca araştırmaların değil aynı zamanda medyanın, kitapların ve filmlerin, ilişkisel saldırganlık konusuna ilgi gösterdiğini vurgulamıştır. Crick ve Grotpeter (1995) ilişkisel saldırganlığı, dışlama ya da dedikodu yoluyla sosyal ilişkilere zarar verme olarak tanımlarken, Underwood, Galen ve Paquette (2001), statü kazanma amacı ile diğerlerine psikolojik ve duygusal zarar verme girişimi olarak tanımlar. Daha önce belirtildiği gibi, ergenlik dönemi yakın ilişkilerin ve sosyal statünün önem kazandığı bir dönemdir, dolayısıyla bu dönemde bireyler bilişsel ve sosyal kazanımlarının yardımıyla ilişkisel saldırganlık taktiklerini daha kolaylıkla uygulayabilir hale gelirler (Card, Stucky, Sawalani ve Little, 2008; Santrock, 2014).

Yapılan çalışmalar, ilişkisel saldırganlığın biyolojik, sosyal ve bilişsel süreçlerle ilişkili olduğunu göstermektedir. Örneğin, öz-düzenleme ve duygusal tepkisellik gibi erken dönemde ortaya çıkan mizaç özelliklerinin, ilişsisel saldırganlıkla ilişkili olduğunu gösteren çalışmaların yanı sıra (Dane ve Marini, 2014), duygu düzenleme stratejilerinin (Kokkinos, Algiovanoglou, ve Voulgaridou, 2019; Yoon, Barton ve Taiariol, 2004) söz konusu davranışlarla ilişkili olduğunu bulan çalışmalar mevcuttur. Duygu düzenleme, kişinin belli bir amaca ulaşma hedefiyle, duygularını tanıyabilmesi, duygusal tepkilerini gözlemlemesi, kontrol atında tutabilmesi, değiştirebilmesi ve uygun biçimlere dönüştürebilmesi olarak tanımlanmaktadır (Cole, Martin ve Dennis, 2004; Eisenberg, Champion ve Ma, 2004). Dolayısıyla, duygu düzenleme becerileri, kişinin sosyal çevresi ile olan ilişkilerine olumlu katkı sağlamaktadır. Gross ve Thompson (2007) duygu düzenlemenin, duygu seçimi (ortama uygun duygu ve tepkiyi seçme), durumu ayarlama (duygunun ifade edilmesinde durumun manipüle edilmesi), dikkatini verme, bilişsel değişim (duyguya bağlı olarak bilişsel yapının ayarlanması) ve tepkinin değişimi olmak üzere aşamalarının bulunduğunu belirtmiştir. Dolayısıyla saldırganlık davranışlarının gerçekleşmesinde olumsuz duyguların düzenlenmesinde yaşanan güçlüklerin de etki edebileceği düşünülebilir. Cole ve ark (1994), duygu düzenlemeyi ikili bir süreç olarak değerlendirir: "yetersiz ve aşırı düzenleme". Yetersiz düzenleme yapan bireylerde dürtü kontrolü zayıftır, saldırgan davranışlar bu şekilde ortaya çıkabilir; aşırı düzenlemede ise, anksiyete, depresyon gibi patolojiler görülebilir. Duygu düzenlemenin iyi bir şekilde yapılabiliyor olması ve davranışsal kontrolün oluşumuna katkı sağlaması, kişinin dürtüselliğinde ve dolayısıyla saldırgan davranışlarında azalma ile sonuçlanabilir (Gross ve Thompson, 2007). Benzeri biçimde, duygu düzenleme becerileri iyi olanların, daha az davranış problemi yaşadıkları görülmüştür (Blandon ve ark., 2010; Bowie, 2010; Silk, Steinberg ve Morris, 2003). McLaughlin ve ark (2014), duygu düzenlemede azalmanın, içsel ve çevresel uyaranların değerlendirilmesinde bozulmaya dolayısıyla uygun tepkilerin verilememesine ve saldırganlığa yol açtı̆̆ını belirtirken; Sullivan ve ark (2010), olumsuz duyguları düzenlemede sorun yaşayan ergenlerin, saldırgan davranışlarında artış olduğunu bulmuş ve bunu bir "savunma mekanizması" olarak geliştirdiklerini belirtmiştir.

Daha önce belirtildiği gibi ilişkisel saldırganlık biyolojik, duygusal ve çevresel unsurlarla ilişkilidir. Dolayısıyla ergenin ebeveyni ile olan ilişkileri de, saldırganlık davranışlarının görülmesinde önemli faktörlerden biri 
olarak görülmektedir. Dolayısıyla ilişkisel saldırganlık, disiplin teknikleri, bağlanma, ebeveyn tutumu unsurlarıyla ilişkisi bakımından incelenmiştir (Casas ve ark. 2006; Kokkinos ve ark., 2019; Underwood, Beron ve Rosen, 2009). Bununla birlikte ebeveynin kontrol davranışlarının, özellikle ergenlik döneminde, ilişkisel saldırganlık ile ilişkisini ortaya koyan çalışmalar mevcuttur (Gaertner ve ark. 2010; Nelson ve Crick, 2002; Nelson, Hart, Yang, Olsen ve Jin, 2006; Petit ve ark. 2001)..

Psikolojik kontrol, ebeveynlerin, bağımlılığı arttırmak, bireyselleşmeyi kısıtlamak ve çocuğun benlik hissini geçersiz kılmaya çalışmak gibi çeşitli psikolojik taktikler yoluyla çocuğun davranışını kontrol etme girişimleri olarak açıklanmaktadır (Barber ve Harmon, 2002). Ebeveynler tarafindan kullanılan bu taktikler çocuğun anksiyetesinin artmasına, suçluluk duymasına ve ebeveynin isteklerine ve taleplerine boyun eğmesine yol açar. Ebeveyn tarafindan uygulanan psikolojik kontrol, özerkliğin gelişiminde, psikolojik olgunlaşmada olumsuz etkileri yol açmaktadır (Barber, 1996; Kindap ve ark., 2008). Psikolojik kontrol, ergenlerin kendini ifade etme özgürlüklerini kısıtlayan, ebeveynlerin ergenin psikolojik ihtiyaçlarına duyarlı olmamasına neden olan, suçlayıcı, utandırıcı ve sevgiyi esirgeyici davranışları beraberine getiren bir kavramdir (Barber ve Harmon, 2002). Psikolojik kontrol ebeveynlerin çocuklar üzerinde uyguladıkları aşırı kontrolcü davranış ve tutumlar olmasının yanında benlik saygısını da olumsuz yönde etkilemektedir. Kındap ve ark (2008) ebeveynlerin uyguladığı psikolojik kontrolün ergende içsel bir kaygı ve gerilim yarattığını, ergenin bu gerilimden kurtulmak adına saldırgan davranışlarda bulunduğunu belirtmiştir. Benzeri biçimde, Gaertner ve ark (2010) ebeveynlerin uyguladığı psikolojik kontrolün ergenin ilişkileri doğrultusunda ilişkisel saldırganlıkla ilişkili olduğunu bulmuştur. Loukas ve ark (2005) annenin psikolojik kontrolüne düşük düzeyde maruz kalan ergenlerde sosyal ve açık saldırganlık puanının, yüksek düzeyde kontrole maruz kalanlara göre düşük olduğunu bulmuştur.

Davranışsal kontrol, ebeveynlerin çocukları üzerindeki müdahaleci tutumlardır. Pomerantz ve Wang (2009) davranışsal kontrolün düzeyinin önemini vurgulayarak, orta düzeydeki kontrolün, ebeveynlerin çocukları için rehberlik yapmaları, izlemeleri ve kabul edilebilir kurallar koymaları olarak ifade eder, düşük düzeydeki kontrol ise çocuğa hiç müdahale edilmemesi ile sonuçlanmaktadır. Yüksek düzeyde kontrolde ise aşırı baskıcı, müdahaleci ve kuralcı ebeveyn davranışları görülmektedir Davranışsal kontrolün odağında, çocuğa uygun davranışların kazandırılması amacı vardır. Ebeveynler çocukların tutum ve tavırlarına, çalışma düzenlerine, arkadaşları ile geçirdikleri zamanlara ve aktivitelere müdahalede bulunarak bunları kendi istekleri doğrultusunda düzenlemek isterler. Bu noktada kurallarla birlikte istenen davranış öğretilmeye çalışılır ve davranışın sürekliliği için davranışlar izlenir (Kerr ve Stattin, 2003). İzleme davranışsal kontrolün temel öğelerinden biridir çünkü ebeveynler çocuklarının nerede olduklarını, ne yaptıklarını ve kimlerle olduklarını denetlemek isterler. Bu durum ebeveynlerin çocukları için ailesel ve toplumsal standartlara uymak ve bunları içselleştirmenin bir yolu olarak görmelerinden gelmektedir (Pettit ve ark, 2001).

Davranışsal kontrol düzeyi ergenlerin saldırgan davranışlarıyla ilişkili bulunmuştur. McLeod ve ark (2007) yüksek düzeyde davranışsal kontrole maruz kalan ergenlerin kendilerini ve çevreyi tanımalarında uygun imkânları yaratamadıklarını, bu durum ergenin mevcut kaygılarının artmasına sebep olduğunu belirtmiştir. $\mathrm{Bu}$ durum da, kaygı ve stresi ailesine ve çevresine karşı saldırgan davranışlar sergilemesini tetikleyebilir. Benzeri biçimde, Pettit ve ark (2001) yüksek düzeyde kontrolün, ebeveynlere öfke ve saldırganlı gibi antisosyal davranışlarla ilişkili olduğunu göstermiştir. Maccoby ve Martin (2003) ise, davranışsal kontrolün dışsallaştırma sorunları üzerindeki etkisini vurgulamıştır. Ergen ebeveynlerin kendisi için düşündüğü profile uymak, davranışlarda bulunmak ve sosyalleşmek zorunda kalır, bu durum kişinin kendisinin farkına varmasını ve kendi duygu ve düşüncelerini özgürce ifade etmesini engelleyebilir, bu durum da ikili ilişkilerinde sorunlara yol açabilir. Buna karşın, davranışsal kontrolün ergenler üzerinde olumlu etkileri de bulunmaktadır. Ebeveynler çocukların yaşantısına aşırı müdahaleci olarak onların sapkın arkadaşlarla ilişkide olmasına ve olumsuz davranışları öğrenme ortamı yaratılmasını engelleyebilmektedirler (Sayıl ve ark., 2012). Morrison ve ark (2012) Latin-Amerikalı ergenlerle yaptıkları çalışmada, ebeveyn izlemesinin algılanan sosyal desteği arttırdığı ve saldırganlık, hırsızlık vb. antisosyal davranışları azalttığını göstermiştir. Benzeri biçimde Tepe ve Sayıl (2012) tarafindan yapılan çalışmada, annenin davranışsal kontrolü arttığında, kızların ilişkisel saldırganlığının azaldığı görülmüştür, ancak erkeklerde aynı sonuca rastlanmamıştır.

Scharf ve Goldner (2018) tarafindan önerilen modelde, psikolojik kontrol ve problemleri içselleştirme ve dışsallaştırma, arasındaki ilişkide duygu düzenleme unsuru aracı değişken olarak belirtilmiştir. Dolayısıyla bu çalışmada, bu model test edilmek istenmiş; ebeveynlerin kontrol davranışları ve ergenlerin ilişkisel saldırganlığı arasındaki ilişkide duygu düzenleme güçlügünün aracı rolü incelenmiştir. Bunun yanında, ilişkisel saldırganlıkta cinsiyet değişkeni bakımından birtakım farklılıklar olduğu görülmektedir. Örneğin Crick (1995) yaptığı çalışmada, kızların daha fazla ilişkisel saldırganlık gösterdiğini ve sıkıntılı durumlarda daha kolay provoke olduğunu belirtmiştir. Buna karşın, Galen ve Underwood (1997) cinsiyetler arasında farklılık bulmamıştır. Dolayısıyla bu çalışmada, hem kız hem de erkek örneklemin ayrı bir şekilde değerlendirilmesi hedeflenmiş̧tir.

\section{Yöntem}

\section{Katılımcılar}

Çalışmada Zonguldak ilinin çeşitli ilçelerinde bulunan özel lise ve devlet liselerinde okuyan, yaşları 14-17 arasında değişen 156 's $\mathrm{k}$ kı ve 164 'ü erkek toplam 320 ergen bulunmaktadır. 
Tablo 1.

Katılımcıların Demografik Özellikleri

\begin{tabular}{|c|c|c|c|}
\hline Değișkenler & & n & $\%$ \\
\hline \multirow{4}{*}{ Yaş } & 14 yaş & 65 & 20,3 \\
\hline & 15 yaş & 94 & 29,4 \\
\hline & 16 yaş & 118 & 36,9 \\
\hline & 17 yaş & 43 & 13,4 \\
\hline \multirow{2}{*}{ Cinsiyet } & $\mathrm{K}_{12}$ & 156 & 48,8 \\
\hline & Erkek & 164 & 51,2 \\
\hline \multirow{2}{*}{ Maddi durum } & İyi & 147 & 45,9 \\
\hline & Orta & 173 & 54,1 \\
\hline \multirow{2}{*}{ Okul başarısı } & İyi & 106 & 33,1 \\
\hline & Orta & 214 & 66,9 \\
\hline \multirow{4}{*}{ Sinıf } & 9. sinif & 126 & 39,4 \\
\hline & 10. sinıf & 48 & 15,0 \\
\hline & 11. sinıf & 113 & 35,3 \\
\hline & 12. sinıf & 33 & 10,3 \\
\hline \multirow{4}{*}{ Kardeş sayısı } & Tek çocuk & 21 & 6,6 \\
\hline & Tek kardeş & 29 & 9,1 \\
\hline & 2 kardeş & 150 & 46,9 \\
\hline & 3 kardeș ve üzeri & 120 & 37,5 \\
\hline \multirow{4}{*}{ Doğum sırası } & Tek çocuk & 21 & 6,6 \\
\hline & İlk çocuk & 155 & 48,4 \\
\hline & Ortanca çocuk & 35 & 10,9 \\
\hline & Son çocuk & 109 & 34,1 \\
\hline Toplam & & 320 & 100,0 \\
\hline
\end{tabular}

\section{Veri Toplama Araçları}

\section{Sosyodemografik Bilgi Formu}

Araştırmacı tarafindan oluşturulan ve katılımcıların yaş, cinsiyet, aile maddi durum, okul başarısı gibi bilgilerinin yer aldığı bilgi formudur.

\section{Arkadaşlık İlişkilerinde İlişkisel Saldırganlık Ölçeği}

Kişilerin ilişkisel saldırganlık düzeylerinin ölçülmesi amaciyla Kurtyılmaz, Can ve Ceyhan (2017) tarafindan geliştirilen ölçektir. Ölçekte beşli likert tipinde $(1=$ hiçbir zaman, 5 = her zaman) 22 madde bulunmaktadır. Ölçekte ters madde bulunmamaktadır. Ölçek ilişkisel saldırganlığın dışlama, manipülasyon ve dedikodu boyutlarını ölçmektedir. $\mathrm{Bu}$ çalışmanın analizlerinde, ölçeğin toplam puanı kullanılmıştır. Ölçekten alınan yüksek puan ilişkisel saldırganlık düzeyinin yüksek olduğunu göstermektedir. Orijinal çalışmada ölçek geneli için 0,91'lik Cronbach Alfa katsayısı bulunmuştur. Bu çalışmada Cronbach Alfa katsayısı 0,93 olarak bulunmuştur.

\section{Duygu Düzenleme Güçlüğ̈̈ Ölçeği-Kısa Form}

Kişilerin duygu düzenleme güçlüğü düzeylerinin ölçülmesi amaciyla Bjureberg ve arkadaşları (2016) tarafından geliştirilen ölçektir. Ölçekte beşli likert tipinde ( 1 = hemen hemen hiç, $5=$ hemen hemen her zaman) 16 madde bulunmaktadır. Ölçek duygu düzenleme güçlüğünün açıklık, amaçlar, dürtü, stratejiler ve kabul etmeme boyutlarını ölçmektedir. $\mathrm{Bu}$ çalışmanın analizlerinde, ölçeğin toplam puanı kullanılmıştır. Ölçekten alınan yüksek puan duygu düzenleme güçlüğü düzeyinin yüksek olduğunu göstermektedir. Ölçeğin Türkçe güvenirlik ve geçerlik çalışması Yiğit ve Yiğit (2019) tarafından yapılmıştır. Orijinal çalışmada ölçek geneli için 0,92'lik Cronbach Alfa katsayısı bulunurken uyarlama çalışmasında da bu değer 0,92 olarak hesaplanmıştır. $\mathrm{Bu}$ çalışmada Cronbach Alfa katsayısı 0,91 olarak bulunmuştur.

\section{Psikolojik Kontrol Ölçeği}

Kișilerin ebeveynlerinden algıladıkları psikolojik kontrol düzeylerinin ölçülmesi amacıyla Barber ve arkadaşları (2007) tarafindan geliştirilen ölçektir. Ölçekte dörtlü likert tipinde $(1=$ hiç benzemiyor, $4=$ çok benziyor $) 16$ madde bulunmaktadır. Ölçekte her ifade hem anne hem de baba için yanıtlanmaktadır. Ölçek ebeveyn psikolojik kontrolünün anne saymazlık, anne psikolojik kontrol, baba saymazlık ve baba psikolojik kontrol boyutlarını ölçmektedir. $\mathrm{Bu}$ çalı̧̧mada yalnızca ebeveynlerin psikolojik kontrol boyutları değerlendirilmiştir. Ölçeğin Türkçe güvenirlik ve geçerlik çalışması Sayıl ve Kındap (2010) tarafindan yapılmıştır. Orijinal çalışmada, anne psikolojik kontrol için 0,88 ve baba psikolojik kontrol için 0,90'lı Cronbach Alfa katsayısı bulunurken uyarlama çalışmasında anne psikolojik kontrol için 0,77 ve baba psikolojik kontrol için 0,79'luk Cronbach Alfa katsayısı bulunmuştur. $\mathrm{Bu}$ çalışmada bulunan geçerlik katsayıları sirasıyla 0,82 ve 0,82 'dir.

\section{Davranışsal Kontrol Ölçeği}

Kişilerin ebeveynlerinden algıladıkları davranışsal kontrol düzeylerinin ölçülmesi amaciyla Vazsonyi, Hibbert ve Snider (2003) tarafindan geliştirilen ölçektir. Ölçekte beşli likert tipinde $(1=$ hiç uygun değil, $5=$ çok uygun) 8 madde bulunmaktadır. Ölçekte ters madde bulunmamaktadır. Ölçekte her ifade hem anne hem de baba için yanıtlanmaktadır. Ölçekten alınan yüksek puan algılanan ebeveyn davranışsal kontrol düzeyinin yükssek olduğunu göstermektedir. Ölçeğin Türkçe güvenirlik ve geçerlik çalışması Sayıl ve ark (2012) tarafından yapılmıştır. Orijinal çalışmada anne davranışsal kontrol için 0,78 ve baba davranışsal kontrol için 0,80'lik Cronbach Alfa katsayıs1 bulunurken uyarlama çalışmasında anne davranışsal kontrol için 0,80 ve baba davranışsal kontrol için 0,83'lük Cronbach Alfa katsayısı bulunmuştur. Bu çalışmada anne davranışsal kontrol için 0,81 ve baba davranışsal kontrol için $0,88^{\prime}$ lik Cronbach Alfa katsayısı bulunmuştur. 


\section{İşlem}

Çalışmanın başlangıcında üniversitenin (Maltepe Üniversitesi) Etik Kurul komisyonundan çalışmanın yapılması için gerekli izin alınmıştır (Karar No: 2019/5/11). Söz konusu izin 5 Kasım 2019 tarihinde verilmiştir. Daha sonrasında, veri toplama işlemine geçilmeden önce Milli Eğitim Müdürlüğünden gerekli uygulama izni alınmıştır. Katılımcılara çalışma hakkında gerekli bilgi verilmiş, katılımcılardan ve velilerinden onam formu doldurmaları istenmiştir. Ardından katılımcılar gönüllü olarak anketleri doldurmuşlardır.
Toplanan 350 anket içerisinde 30 kişinin yanıtlarının eksik olduğunun görülmesinin ardından veri setinden çıkarılmış ve 320 kişi üzerinden analizler yapılmıştır.

\section{Bulgular}

$\mathrm{Bu}$ bölümde öncelikle değişkenler ile ilgili betimleyici istatistikler ve değişkenlerin cinsiyet bakımından karşılaştırmaları verilmiştir. Yapılan bağımsız gruplar $t$ testi sonucunda kızlar ve erkekler arasında, değişkenlerin hiçbiri bakımından anlamlı düzeyde farklılık bulunmamıştır (bkz. Tablo.2).

\section{Tablo 2.}

Değişkenlerin Betimleyici İstatistikleri ve Cinsiyet Karşılaştırmaları

\begin{tabular}{|c|c|c|c|c|c|c|c|c|c|c|c|}
\hline \multirow[b]{2}{*}{ Değişkenler } & \multicolumn{3}{|c|}{ Toplam } & \multicolumn{3}{|c|}{$\mathbf{K} \mathbf{\prime z}$} & \multicolumn{3}{|c|}{ Erkek } & \multirow[b]{2}{*}{$\mathbf{t}$} & \multirow[b]{2}{*}{$\mathbf{p}$} \\
\hline & $\mathbf{N}$ & $\bar{x}$ & Ss & $\mathbf{N}$ & $\overline{\mathbf{x}}$ & SS & $\mathbf{N}$ & $\overline{\mathbf{x}}$ & Ss & & \\
\hline Duygu Düzenleme Güçlüğü & 320 & 35.13 & 12.76 & 156 & 36.44 & 13.24 & 164 & 33.87 & 12.18 & 1.80 & .07 \\
\hline İlişkisel Saldırganlık & 320 & 44.80 & 16.77 & 156 & 44.22 & 16.68 & 164 & 45.35 & 16.88 & -.60 & .54 \\
\hline Anne Psikolojik Kontrol & 320 & 16.68 & 5.07 & 156 & 16.56 & 4.97 & 164 & 16.79 & 5.17 & -.41 & .68 \\
\hline Baba Psikolojik Kontrol & 320 & 15.68 & 4.67 & 156 & 15.53 & 4.59 & 164 & 15.80 & 4.75 & -.50 & .61 \\
\hline Anne Davranışsal Kontrol & 320 & 31.63 & 5.79 & 156 & 32.21 & 5.49 & 164 & 31.07 & 6.03 & 1.77 & .07 \\
\hline Baba Davranışsal Kontrol & 320 & 27.38 & 7.78 & 156 & 26.59 & 8.13 & 164 & 28.12 & 7.36 & -1.76 & .07 \\
\hline
\end{tabular}

Yapılan korelasyon analizi tablosunda görüldüğü üzere, duygu düzenleme güçlügünün, anne davranışsal kontrolü dışındaki değişkenlerle anlamlı düzeyde ilişkili olduğu görülmüştür (Bkz. Tablo 3). Bunun yanında, duygu düzenleme güçlügü, annenin ve babanın psikolojik kontrolü ile pozitif yönde, babanın davranışsal kontrolü ile negatif yönde iliş̧kilidir. İlişkisel saldırganlık için de aynı durum geçerlidir, annenin ve babanın psikolojik kontrolü ilişkisel saldırganlıkla pozitif yönde ilişkilidir; davranışsal kontrol ile negatif yönde ve anlamlı düzeyde ilişkilidir. İlişkisel saldırganlığın aynı zamanda, pozitif yönde ve anlamlı düzeyde duygu düzenleme güçlügü ile ilişkili olduğu görülmektedir. Bu durum tüm örneklem grubu, kız ve erkek örneklemler için geçerlidir.

Tablo 3. Değişkenlere İlişkin Korelasyon Tablosu

\begin{tabular}{|c|c|c|c|c|c|c|c|}
\hline Değișkenler & 1 & 2 & 3 & 4 & 5 & 6 & N (Toplam) \\
\hline 1.Duygu Düzenleme Güçlüğü & & $279 * *$ & $285^{* *}$ &, $374 * *$ &,- 077 &,$- 246 * *$ & 320 \\
\hline 2.İlişkisel Saldırganlık & & & $256^{* *}$ & $222 * *$ &,$- 207 * *$ &,$- 226 * *$ & 320 \\
\hline 3.Anne Psikolojik Kontrol & & & &, $744 * *$ &,$- 157 * *$ &,$- 296 * *$ & 320 \\
\hline 4.Baba Psikolojik Kontrol & & & & &,$- 159 * *$ &,$- 259 * *$ & 320 \\
\hline 5.Anne Davranışsal Kontrol & & & & & & $700 * *$ & 320 \\
\hline 6. Baba Davranışsal Kontrol & & & & & & & 320 \\
\hline Değișkenler & 1 & 2 & 3 & 4 & 5 & 6 & $\mathbf{N}(\mathbf{K} \mathbf{\prime z})$ \\
\hline 1.Duygu Düzenleme Güçlüğü & & $326^{* *}$ & ,193* & $331^{\text {** }}$ &,- 077 &,$- 262^{* *}$ & 156 \\
\hline 2.İlişkisel Saldırganlık & & & $290^{* *}$ & $235^{* *}$ &,$- 170^{*}$ &,$- 236^{* *}$ & 156 \\
\hline 3.Anne Psikolojik Kontrol & & & & $604^{* *}$ &,- 110 &,$- 307^{* *}$ & 156 \\
\hline 4.Baba Psikolojik Kontrol & & & & &,- 117 &,$- 264^{* *}$ & 156 \\
\hline 5.Anne Davranışsal Kontrol & & & & & & $678^{* *}$ & 156 \\
\hline 6. Baba Davranışsal Kontrol & & & & & & & 156 \\
\hline Değişkenler & 1 & 2 & 3 & 4 & 5 & 6 & N (Erkek) \\
\hline 1.Duygu Düzenleme Güçlüğü & &, $242^{* *}$ &, $386^{* *}$ & $429^{* *}$ &,- 099 &,$- 212^{* *}$ & 164 \\
\hline 2.İlişkisel Saldırganlık & & & $224^{* *}$ & $208^{* *}$ &,$- 234^{* *}$ &,$- 225^{* *}$ & 164 \\
\hline 3.Anne Psikolojik Kontrol & & & & $868^{\text {** }}$ &,$- 194^{*}$ &,$- 294^{* *}$ & 164 \\
\hline 4.Baba Psikolojik Kontrol & & & & &,$- 191^{*}$ &,$- 263^{* *}$ & 164 \\
\hline 5.Anne Davranısssal Kontrol & & & & & & $76^{* *}$ & 164 \\
\hline 6. Baba Davranıșsal Kontrol & & & & & & & 164 \\
\hline
\end{tabular}

$* * \mathrm{p}<.01 ; * \mathrm{p}<.05$

Buradan hareketle, duygu düzenleme güçlüğünün, annenin ve babanın psikolojik kontrolü, babanın davranışsal kontrolü ve ilişkisel saldırganlık arasındaki aracı rolünü incelemek için Hayes (2013) tarafindan yazılan PROCESS kullanılmıştır. Annenin davranışsal kontrolü, arac1 modelde test edilmemiştir, çünkü duygu düzenleme ve annenin davranışsal kontrolü arasında, toplam, kız ve erkek örneklemlerin hiçbirinde anlamlı bir ilişki bulunmamıştır. Analiz Bootstrapping yöntemiyle incelenmiştir. Orijinal veriden yeniden elde edilen 5000 yeni örnekleme dayalı güven aralıkları değerlendirilmiştir. Kız ve erkek örneklem grubu ayrı ayrı incelenmiştir.

Kızlarda, annenin psikolojik kontrolünün, ilişkisel saldırganlık üzerinde pozitif yönde anlamlı bir toplam etkisi olduğu $(\mathrm{B}=.97 \quad \mathrm{SE}=.25, \mathrm{p}<.001)$ bulunmuştur. Duygu düzenleme modele dahil edilmediğinde $(B=.79$, $\mathrm{SE}=.25, \mathrm{p}<.01)$ anlamlılık azalmıştır. Dolayısıyla, duygu düzenleme güçlügünün anne psikolojik kontrol ve ilişkisel saldırganlık arasındaki ilişkide aracı rolü olduğu bulunmuştur $[\mathrm{B}=.18, \mathrm{SE}=.08,95 \%$ CI $(.0424, .3681)]$. 
Babanın psikolojik kontrolünün, ilişkisel saldırganlık üzerinde pozitif yönde anlamlı bir toplam etkisi olduğu $(\mathrm{B}=.85 \mathrm{SE}=.28, \mathrm{p}<.01)$ bulunmuştur. Duygu düzenleme modele dahil edilmediğinde $(\mathrm{B}=.51, \mathrm{SE}=.29, \mathrm{p}>.05)$ anlamlılık ortadan kalkmıştır. Dolayısıyla, duygu düzenleme güçlügünün baba psikolojik kontrol ve ilişkisel saldırganlık arasındaki ilişkide aracı rolü olduğu bulunmuştur $[\mathrm{B}=.33, \mathrm{SE}=.10,95 \% \mathrm{CI}(.1713, .5968)]$. Babanın davranışsal kontrolünün ve ilişkisel saldırganlık üzerinde negatif yönde anlamlı bir toplam etkisi olduğu $(\mathrm{B}=-.48 \mathrm{SE}=.16, \mathrm{p}<.01)$ bulunmuştur. Duygu düzenleme modele dahil edilmediğinde $(\mathrm{B}=-.33, \mathrm{SE}=.16, \mathrm{p}<.05)$ anlamlılık azalmıştır. Dolayısıyla, duygu düzenleme güçlügünün baba davranışsal kontrol ve ilişkisel saldırganlık arasındaki ilişkide aracı rolü olduğu bulunmuştur $[\mathrm{B}=-.15, \mathrm{SE}=.05,95 \%$ CI $(.-.2785,-$ .0637)].

Erkeklerde, annenin psikolojik kontrolünün, ilişkisel saldırganlık üzerinde pozitif yönde anlamlı bir toplam etkisi olduğu $(\mathrm{B}=.73 \mathrm{SE}=.24, \mathrm{p}<.01)$ bulunmuştur. Duygu düzenleme modele dahil edilmediğinde $(\mathrm{B}=.49, \mathrm{SE}=.26$, $\mathrm{p}>.05)$ anlamlılık ortadan kalkmıştır. Dolayısıyla, duygu düzenleme güçlügünün anne psikolojik kontrol ve ilişkisel saldırganlık arasındaki ilişkide aracı rolü olduğu bulunmuştur $[\mathrm{B}=.23, \mathrm{SE}=.12,95 \% \mathrm{CI}(.0159, .5017)]$. Babanın psikolojik kontrolünün, ilişkisel saldırganlık üzerinde pozitif yönde anlamlı bir toplam etkisi olduğu $(\mathrm{B}=.73 \mathrm{SE}=.27, \mathrm{p}<.01)$ bulunmuştur. Duygu düzenleme modele dahil edilmediğinde $(\mathrm{B}=.45, \mathrm{SE}=.29, \mathrm{p}>.05)$ anlamlılık ortadan kalkmıştır. Dolayısıyla, duygu düzenleme güçlügünün baba psikolojik kontrol ve ilişkisel saldırganlık arasındaki ilişkide aracı rolü olduğu bulunmuştur $[\mathrm{B}=.28, \mathrm{SE}=.14,95 \%$ CI $(.0069, .5863)]$. Babanın davranışsal kontrolünün ve ilişkisel saldırganlık üzerinde negatif yönde anlamlı bir toplam etkisi olduğu $(\mathrm{B}=-.51 \mathrm{SE}=.17, \mathrm{p}<.01)$ bulunmuştur. Duygu düzenleme modele dahil edilmediğinde $(\mathrm{B}=-.41, \mathrm{SE}=.17, \mathrm{p}<.05)$ anlamlılık azalmıştır. Dolayısıyla, duygu düzenleme güçlüğünün baba davranışsal kontrol ve ilişkisel saldırganlık arasındaki ilişkide aracı rolü olduğu bulunmuştur $[\mathrm{B}=-.09, \mathrm{SE}=.05,95 \% \mathrm{CI}(-.2585,-.0179)]$.

\section{Tartışma}

$\mathrm{Bu}$ çalışmada, ergenlerin ilişkisel saldırganlık ve ebeveyn kontrolü arasındaki ilişkide duygu düzenlemenin aracı rolü incelenmiştir. Duygu düzenlemenin aracı rolüne bakılmadan önce, değişkenler arasındaki ilişkiler tespit edilmiştir. Buna göre, ebeveynin psikolojik kontrolü ile ilişkisel saldırganlık pozitif yönde, davranışsal kontrol ile negatif yönde ilişkilidir. Yapılan çalışmalar benzeri sonuçları işaret etmektedir. Örneğin, Kuppens ve ark (2009) tarafindan yapılan çalışmada, ebeveynin psikolojik kontrolünün hem k1z hem de erkek örneklemde, ilişkisel saldırganlıkla ilişkili olduğu bulurken, fiziksel saldırganlık ile ilişkili olmadığını bulmuştur. Bandura (1973) sosyal öğrenme kuramına göre, ebeveynin davranışları çocukların onları model almasına ve uygulamasına olanak sağlamaktadır, dolayısıyla çocukların saldırgan davranışları ebeveynlerle paralellik gösterebilir, örneğin fiziksel ceza uygulamayı tercih eden ebeveynlerin çocukları fiziksel saldırganlığı, psikolojik kontrol sergileyen ebeveynlerin çocukları da ilişkisel saldırganlık taktiklerini ebeveynlerden öğrenebilir (akt. Shaffer, 2008).
Davranışsal kontrol ve ilişsisel saldırganlık arasındaki ilişkinin bulgularına bakıldığında birtakım çalışmalar davranışsal kontrolün aşırı düzeyde olmasının, dışsallaştırma problem davranışları ile paralellik gösterdiğini bulgularken (McLeod ve ark., 2007; Petit ve ark., 200) diğer çalışmalar, kontrol düzeyinin ergenin aktivitelerini izleme, takip etme olanağı verdiği için, saldırganlık davranışları ile negatif yönde ilişkili olduğunu göstermiştir (Morrison ve ark., 2012; Sayıl ve ark.,2012; Tepe ve Sayıl, 2012). Mevcut çalışmanın bulguları sadece davranışsal kontrolünün ergenlerin ilişkisel saldırganlığı ile negatif ilişkili olduğunu göstermektedir; ergenlerin aktivitelerinin izlenmesi, ancak bu izlemenin ergenin özerkliğini geliştirmesine engel olmayacak biçimde yapılmasının bu duruma etki ettiği düşünülmektedir. Nitekim Aizpitarte ve ark (2019) yaptıkları çalışmada, düşük düzey davranışsal kontrolün, ergenlerin ilişkisel saldırganlığı ile ilişkili olduğunu bulmuştur. Ebeveynleri tarafindan aktiviteleri düzgün biçimde takip edilmeyen, yol gösterilmeyen ergenlerin, akranlarına yönelik ilişkisel saldırganlığının daha fazla olduğu görülmüştür. $\mathrm{Bu}$ bağlamda, ebeveynin ergenin aktivitelerine yönelik izleme davranışları, çocuğun akranları ile ilişkisinde bir rehberlik görevi üstlenerek, uygun davranışların öğrenilmesi ve düzenlenmesine yardımcı olabilir ve dolayısıyla ergenin akran ilişkilerine olumlu katkı sağlayabilir.

$\mathrm{Bu}$ çalışmada test edilen model doğrultusunda yapılan analizlerde, hem annenin hem de babanın psikolojik kontrolü ve hem kız hem de erkek ergenlerin ilişkisel saldırganlığı arasındaki ilişkide, duygu düzenlemenin arac1 rolü bulunmuştur. Buna göre, annenin psikolojik kontrolü doğrudan ilişkisel saldırganlığın görülmesine etki ederken, ergen kızların deneyimlediği duygu düzenleme güçlüğü, dolaylı yoldan ilişkisel saldırganlığın ortaya çıkmasına katkı sağlamaktadır. Duygu düzenlemede yaşanan güçlükler, duyguları ve dürtüleri kontrol edebilme, amaca yönelik eylemde bulunabilme gibi unsurları etkilemektedir (Blandon ve ark., 2010; Bowie, 2010; Silk, Steinberg ve Morris, 2003). Dolayısıyla duygu düzenlemede güçlük yaşayan ergenin, akran ilişkilerinde ilişkisel saldırganlık taktiklerini kullanmaya daha yatkın olduğu düşünülebilir.

$\mathrm{Bu}$ çalışmanın bir diğer önemli bulgusu, babanın psikolojik kontrolü ve ergen kızların ilişkisel saldırganlığı arasındaki ilişkide, duygu düzenleme modele dâhil edildiğinde, babanın psikolojik kontrolünün ilişkisel saldırganlık arasındaki ilişki anlamlılı̆̆ını yitirmesidir. $\mathrm{Bu}$ durumda, annenin psikolojik kontrolüne kıyasla babanın psikolojik kontrolü, duygu düzenleme modele dâhil olduğunda, var olan önemini yitirmektedir, dolayısıyla, annenin psikolojik kontrolünün ilişkisel saldırganlığa daha fazla etki edebildiği yorumunda bulunulabilir. İlgili literatürde, bu duruma yönelik karmaşık sonuçlar bulunmaktadır. Birtakım çalışmalar yalnızca annenin psikolojik kontrolünün, iki cinsiyette de davranışsal problemlerle ile ilişkili olduğunu bulgularken (Kuppens ve ark, 2009), bazı çalışmalar annenin psikolojik kontrolünün yalnızca kızlarda anskiyete problemlerine yol açtığını göstermiştir (Petit ve ark., 2001). Bunun yanında, çocuğun mizaç özellikleri de bu durumda rol oynayabilmektedir; örneğin, Zarra-Nezhad ve ark (2015) tarafından yapılan çalışmada, yalnızca annelerin psikolojik kontrolünün, çocuğun mizacindan bağımsız olarak, negatif duygulanımla ilişkili olduğu 
bulunmuştur, babanın psikolojik kontrolü ise, zor mizaçlı çocuklarda, bu türdeki duygulanımla ilişkilidir.

Bunun yanında, annenin ve babanın psikolojik kontrolünün aynı zamanda ergenin duygu düzenleme güçlüğü yaşamasıyla ilişkili olduğu görülmektedir. Psikolojik kontrol, ebeveynin uyguladığı manipülatif taktikleri içermektedir. Morris ve ark (2007), psikolojik kontrolün duygu düzenleme üzerinde yıpratıcı bir etkisi olduğunu öne sürerek, psikolojik kontrol uygulayan ebeveynlerin, çocuğun psikolojik ihtiyaçlarını gözetmeksizin davrandığını, aile içerisinde negatif bir duygulanımın bu bağlamda ortaya çıktığını belirtmiştir. Olumsuz duygusal iklimin yaşandığı evlerde, çocuk hem ebeveynin taleplerini yerine getirmeye çalışmakta, hem de duygusal anlamda bağıml hissedebilmektedir. Ergenlerin duygu düzenleme güçlüğü ve psikolojik kontrol arasındaki ilişki, ebeveynlerin duygu düzenleme açısından doğru model olamadığı, kendi duygularını da düzenlemekte zorlandıkları ve aynı zamanda etkili olabilecek duygusal stratejileri kullanmaktan yoksun olmalarıla da ilgili olabilir (Cui ve ark., 2014). Dolayısıyla mevcut çalışmanın bulguları da, bununla paralellik göstermektedir, her iki ebeveynin de psikolojik kontrolünün artışı, hem kız hem de erkek ergenlerin daha fazla duygu düzenleme güçlüğü yaşamasıyla ilişkilidir.

Hem kız hem erkek ergenlerde, yalnızca babanın davranışsal kontrolü ile ilişkisel saldırganlık arasında duygu düzenlemenin aracı rolü bulunmuştur. Babanın aktivitelerini izleme düzeyi artışı aynı zamanda duygu düzenleme becerilerinin de artışına yol açmakta, annenin davranışsal kontrolü için aynı durum görülmemektedir. Gündelik aktiviteleri izlenen ve bir nevi sosyalizasyon sürecinde desteklenen ergenler, sosyal yaşamlarında duygu ve davranışları üzerinde daha rahat denetim kurabilirler (Aizpitarte ve ark., 2019). Ancak annenin davranışsal kontrolünün bu çalışmada duygu düzenleme ile anlamlı düzeyde ilişkili olmadığı görülmüştür. İlgili literatürle kısmen uyuşmayan bu bulgu, kültürel faktörlerle açıklanabilir. Anneden ziyade, davranışsal kontrol ile ilgili olan izleme, takip etme gibi unsurlar babadan daha fazla bekleniyor olabilir. Örnegin Shek ve Zhu (2019) tarafindan yapılan çalışmada, sadece babaların yüksek düzeyde davranışsal kontrolünün ergenlerin sapma davranışında ani artışa neden olduğu görülmüştür. Söz konusu çalışmada, Batı kültürünün aksine, çalışmanın yapıldığı Çin'de, geleneksel değerlerin ön planda tutulması, aileye ilişkin sorumluluk hissetme gibi kültürel öğelerden kaynaklı farklılıkların, kontrol unsurunu özerkliğe engel teşkil eden bir yapı olarak değerlendirmemesiyle açıklanmıştır.

Özetle, bu çalışmanın bulguları, hem annenin hem de babanın psikolojik kontrolü, kız ve erkek ergenlerin ilişkisel saldırganlığı arasındaki ilişkide duygu düzenleme güçlüğünün aracı rolünü ortaya koymuştur. Psikolojik kontrol hem duygu düzenleme stratejilerinde yetersizliklerle, hem de ilişkisel saldırganlığın ortaya çıkmasıyla ilişkilidir. Bunun yanında yalnızca babanın davranışsal kontrolünün ilişkisel saldırganlıkla olumsuz yönde ilişkili olduğu ve bu ilişkiye duygu düzenlemenin aracılık ettiği bulunmuştur. Dolayısıyla, babanın davranışsal kontrolü, yani izleme, takip etme ve kontrol etme davranışları, bir yandan ergenin duygu ve davranışlarını kontrol edebilmesine bir yandan da ilişkisel saldırganlık taktiklerini uygulamasının önüne geçebilmektedir.

$\mathrm{Bu}$ çalışmanın birtakım sınırlılıkları bulunmaktadır. Kesitsel desenin kullanıldığı bu çalışma, neden sonuç ilişkilerini kurabilmeye olanak sağlamamaktadır. Dolayısıyla, ileride yapılacak çalışmalarda, boylamsal desen kullanılarak ergenlerin ilişkisel saldırganlığının araştırılmasının önemli olduğu düşünülmektedir. Bunun yanında yapılan bir takım çalışmalar kişilik özelliklerinin, hem ilişkisel saldırganlık, hem de ebeveynin kontrol davranışlarıyla olan ilişkileri ortaya koymaktadır (Prinzie ve ark., 2003; Van Heel ve ark. 2019; Zarra-Nezhad ve ark., 2015). Dolayısıyla ileride yapılacak çalışmalarda, ergenlerin kişilik özelliklerinin de çalışmalara dahil edilmesinin yararlı olacağı düşünülmektedir.

\section{Beyannameler}

Etik Onay ve Katılma İzni

Çalışmanın başlangııında üniversitenin (Maltepe Ünversitesi) Etik Kurul komisyonundan çalıșmanın yapılması için gerekli izin alınmıştır (Karar no: 2019/5/11). Katılımcılara çalışma hakkında gerekli bilgi verilmiş, katılımcılardan ve velilerinden onam formu doldurmaları istenmiştir.

\section{Veri ve Materyallerin Mevcudiyeti}

Mevcut çalışma sırasında analiz edilen veri kümeleri, makul talep üzerine ilgili yazardan temin edilebilir. Mevcut çalışma sırasında analiz edilen veri kümeleri katılımcıların gizliliği esası nedeniyle kamuya açık değildir, ancak makul talep üzerine ilgili yazardan alınabilir.

\section{Çıkar Çatışması}

Yazarlar çıkar çatışması olmadığıı beyan eder.

\section{Finansman}

Uygulanamaz.

\section{Yazar Katkılar}

"Ergenlikte Ebeveyn Kontrolü ve İliş̧isel Saldırganlık: Duygu Düzenlemenin Aracı Rolü” başlıklı makalenin, çalışma deseninin tasarlanması, hipotezlerin belirlenmesi ve kuramsal çerçevenin oluşturulması aşamasında tüm yazarlar katkı sağlamışıı. Veri toplanması konusunda Havva Ekşi isimli yazar katkı sunmuştur. Veri analizlerinin yapılması ve yorumlanmasında tüm yazarlar katkı sağlamıştır. Makalenin ana metninin düzenlenmesi ve oluşturulmasında, verilerin raporlanarak, tartışmanın yazılmasında tüm yazarlar katkı sağlamıştır. Makalenin bu aşamadan sonra revize edilip ana metnin yeniden düzenlenmesinde Seda Erzi katkı sağlamıştır. Makalenin nihai haline getirilmesi ve onay verilmesi Seda Erzi tarafindan yapılmıştır. Tüm yazarlar makalenin son halini okumuş ve onay vermiştir.

\section{Teșekkür}

Uygulanamaz

\section{Kaynaklar}

Aizpitarte, A., Atherton, O. E., Zheng, L. R., Alonso- Arbiol, I., \& Robins, R. W. (2019). Developmental precursors of relational aggression from late childhood through adolescence. Child development, 90(1), 117-126.

Barber, B. K. (1996). Parental psychological control: Revisiting a neglected construct. Child Development, 67, 3296-3319.
Barber, B. K., \& Harmon, E. L. (2002). Violating the self: Parental psychological control of children and adolescents.

Blandon, A. Y., Calkins, S. D., Grimm, K. J., Keane, S. P., \& O'Brien, M. (2010). Testing a developmental cascade model of emotional and social competence and early peeracceptance. Development and Psychopathology, 22(4), 737-748. 
Bowie, B. H. (2010). Understanding the gender differences in pathways to social deviancy: relational aggression and emotion regulation. Archives of Psychiatric Nursing, 24(1), 27-37.

Bronfenbrenner, U. (1979). The ecology of human development: Experiments by nature and design. Cambridge, MA: Harvard University Press.

Card, N. A., Stucky, B. D., Sawalani, G. M., \& Little, T. D. (2008). Direct and indirect aggression during childhood and adolescence: A meta- analytic review of gender differences, intercorrelations, and relations to maladjustment. Child development, 79(5), 1185-1229.

Casas, J. F., Weigel, S. M., Crick, N. R., Ostrov, J. M., Woods, K. E., Yeh, E. A. J. (2006). Early parenting and children's relational and physical aggression in the preschool and home contexts. Journal of Applied Developmental Psychology, 27, 209-227.

Cole, P. M., Martin, S. E., \& Dennis, T.A. (2004). Emotion regulation as a scientific construct: Methodological challenges and directions for child development research. Child Development, 75, 317-333

Cole, P. M., Michel, M. K., \& Teti, L. O. D. (1994). The development of emotion regulation and dysregulation: A clinical perspective. Monographs of the society for research in child development, 59(2- 3), 73-102.

Crick, N. R. (1995). Relational aggression: The role of intent attributions, feelings of distress and provocation type. Development and Psychopathology, 7(2), 313-322.

Crick, N. R., \& Grotpeter, J. K. (1995). Relational aggression, gender, and social psychological adjustment. Child development, 66(3), 710-722.

Cui, L., Morris, A. S., Criss, M. M., Houltberg, B. J., \& Silk, J. S. (2014). Parental psychological control and adolescent adjustment: The role of adolescent emotion regulation. Parenting, 14(1), 47-67.

Dane, A. V., \& Marini, Z. A. (2014). Overt and relational forms of reactive aggression in adolescents: Relations with temperamental reactivity and self-regulation. Personality and Individual Differences, 60, 60-66.

Dodge, K. A., \& Coie, J. D. (1987). Social-informationprocessing factors in reactive and proactive aggression in children's peer groups. Journal of personality and social psychology, 53(6), 1146.

Dodge, K. A., Coie, J. D., \& Lynam, D. (2006). Aggression and Antisocial Behavior inYouth. In: Damon W, Eisenberg N, editors. Handbook of child psychology: Vol. 3. Social, emotional, and personality development. 6th. New York: Wiley; 2006.

Eisenberg, N., Champion, C., \& Ma, Y. (2004). Emotion-related regulation: An emerging construct. Merrill-Palmer Quarterly, 50, 236-259.

Gaertner, A. E., Rathert, J. L., Fite, P. J., Vitulano, M, Wynn, P. T., \& Harber, J. (2010). Sources of Parental Knowledge as Moderators of the Relation Between Parental Psychological Control and Relational and Physical/Verbal Aggression. J Child Fam Stud, 19, 607-616.

Galen, B. R., \& Underwood, M. K. (1997). A developmental investigation of social aggression among children. Developmental psychology, 33(4), 589.

Hayes, A. F. (2013). Introduction to mediation, moderation, and conditional process analysis: A regression-based approach. Guilford Publications.

Kerr, M., \& Stattin, H. (2003). Parenting of adolescents: Action or reaction. Children's influence on family dynamics: The neglected side of family relationships, 121-151.
Kındap, Y., Sayıl, M., \& Kumru, A. (2008). Anneden Algilanan Kontrolün Niteliği ile Ergenin Psikososyal Uyumu ve Arkadaşlıkları Arasındaki İlişkiler: Benlik Değerinin Aracı Rolü. Türk Psikoloji Dergisi, 23 (61), 92-107.

Kokkinos, C. M., Algiovanoglou, I., \& Voulgaridou, I. (2019). Emotion regulation and relational aggression in adolescents: Parental attachment as moderator. Journal of Child and Family Studies, 28(11), 3146-3160.

Kuppens, S., Grietens, H., Onghena, P., \& Michiels, D. (2009). Associations between parentalcontrol and children's overt and relational aggression.British Journal of Developmental Psychology, 27(3), 607-623.

Kurtyılmaz, Y., Gürhan, C. A. N., \& Ceyhan, A. A. (2017). Üniversite öğrencilerinin ilişkisel saldırganlık ile benlik saygısı, sosyal bağlılık ve sosyal kaygı düzeyleri arasındaki ilişkiler. Türk Psikolojik Danışma ve Rehberlik Dergisi,7(47), 33-52.

Loukas, A., Paulos, S. K. \& Robinson, S. (2005). Early Adolescent Social and Overt Aggression: Examining the Roles of Social Anxiety and Maternal Psychological Control. Journal of Youth and Adolescence, 34(4), 335-345.

Maccoby, E.E., \& Martin, J.A. (2003). Socialization in the context of the family: Parent-child interaction. In P. H. Mussen (Ed.), Handbook of child psychology. (pp. 1-101). New York: Wiley.

McLaughlin, K. A., Hatzenbuehler, M. L., Mennin, D. S., \& Nolen-Hoeksema, S. (2011). Emotion dysregulation and adolescent psychopathology. A prospective study. Behaviour Research and Therapy, 49(9), 544-554.

McLeod, B.D., Wood, J.J., \& Weisz, J.R. (2007). Examining the association between parenting and childhood anxiety: a metaanalysis. Clinical Psychology Review, 27, 155-172.

Morris, A. S., Silk, J. S., Steinberg, L., Myers, S. S., \& Robinson, L. R. (2007). The role of the family context in the development of emotion regulation. Social Development, 16, 361-388.

Pettit, G. S., Laird, R. D., Dodge, K. A. ve Bates, J. E., \& Criss, M. M. (2001). Antecedents and Behavior problem outcomes of parental monitoring and psychological control. Child Development, 72, 583-598.

Pomerantz, E.M., \& Wang, Q. (2009). The role of parental control in children's developmentin western and east asian countries. Current Directions in Psychological Science, 18, 285 297.

Prinzie, P., Onghena, P., Hellinckx, W., Grietens, H., Ghesquiere, P., \& Colpin, H. (2003). The additive and interactive effects of parenting and children's personality on externalizing behaviour. European Journal of Personality, 17(2), 95-117.

Santrock, J. (2014). Adolescence (15 ${ }^{\text {th }}$ Edition). New York.: McGraw-Hill.

Sayıl, M., \& Kındap, Y. (2010). Ergenin anne-babadan algıladığı psikolojik kontrol: Psikolojik kontrol ölçeğinin geçerlik ve güvenirliği. Türk Psikoloji Yazıları, 13(25), 62-75.

Sayıl, M., Kındap, Y., Bayar, Y., Kurt, D. ve Tığrak, A. (2012). Ergenlik döneminde ebeveynlik ve ergenin psikososyal uyumu. Hacettepe Üniversitesi Yayınları.

Scharf, M., \& Goldner, L. (2018). "If you really love me, you will do/be...": Parental psychological control and its implications for children's adjustment. Developmental Review, 49, 16-30.

Shaffer, D. R. (2008). Social and personality development. Toronto, Canada: Nelson Education.

Shek, D. T., \& Zhu, X. (2019). Paternal and maternal influence on delinquency among early adolescents in Hong 
Kong. International journal of environmental research and public health, 16(8), 1338.

Silk, J. S., Steinberg, L., \& Morris, A. S. (2003). Adolescents' emotion regulation in daily life: Links to depressive symptoms and problem behavior. Child development, 74(6), 1869-1880.

Sullivan, T. N., Helms, S. W., Kliewer, W., \& Goodman, K. L. (2010). Associations between sadness and anger regulation coping, emotional expression, and physical and relational aggression among urban adolescents. Social Development, 19(1), $30-51$

Tepe, Y.K., \& Sayıl, M. (2012). Ebeveyn kontrolü ve ergenin sosyal işlevselliği arasındaki bağlantıda ilişkisel saldırganlığın aracı rolü. Türk Psikoloji Dergisi, 27(70), 119-132

Underwood, M. K., Beron, K. J., \& Rosen, L. H. (2009). Continuity and change in social and physical aggression from middle childhood through early adolescence. Aggressive Behavior: Official Journal of the International Society for Research on Aggression, 35(5), 357-375.

Underwood, M.K., Galen, B.R., \& Paquette, J.A. (2001). Top ten challenges for understanding gender and aggression in children: Why can't we all just get along? Social Development, 10, 268271.

Van Heel, M., Bijttebier, P., Colpin, H., Goossens, L., Van Den Noortgate, W., Verschueren, K., \& Van Leeuwen, K. (2019).
Investigating the interplay between adolescent personality, parental control, and externalizing problem behavior across adolescence. Journal of research in personality, 81, 176-186.

Voulgaridou, I., \& Kokkinos, C. M. (2015). Relational aggression in adolescents: A review of theoretical and empirical research. Aggression and Violent Behavior, 23, 87-97.

Yoon, J. S., Barton, E., \& Taiariol, J. (2004). Relational aggression in middle school: Educational implications of developmental research. The Journal of Early Adolescence, 24(3), 303-318.

Yiğit, İ., Guzey Yiğit, M. (2019). "Psychometric Properties of Turkish Version of Difficulties in Emotion Regulation ScaleBrief Form (DERS-16)." Current Psychology, 38, 1503-1511.

Zarra-Nezhad, M., Aunola, K., Kiuru, N., Mullola, S., \& Moazami-Goodarzi, A. (2015). Parenting styles and children's emotional development during the first grade: The moderating role of child temperament. Journal of Psychology and Psychotherapy, 5.

Zimmer-Gembeck, M. J., Trevaskis, S., Nesdale, D., \& Downey, G. A. (2014). Relationalvictimization, loneliness and depressive symptoms: Indirect associations via self and peer reports of rejection sensitivity. Journal of youth and adolescence, 43(4), $568-582$. 